\title{
BNWL-B -51
}

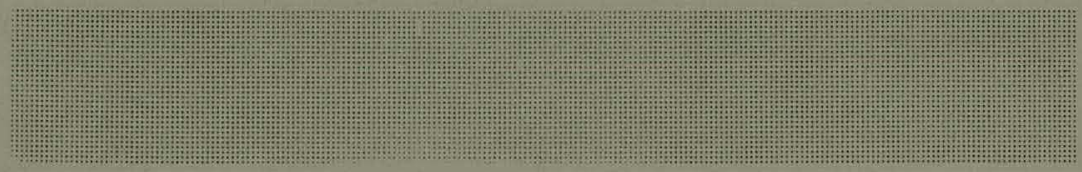

February 1971

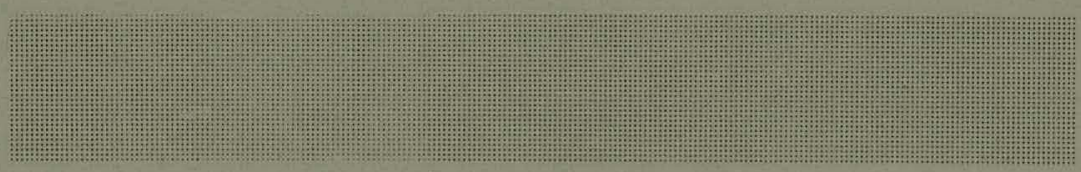

PREPARED FOR

THE UNITED STATES ATOMIC ENERGY COMMISSION

UNDER CONTRACT AT(45-1)-1830 


\section{DISCLAIMER}

This report was prepared as an account of work sponsored by an agency of the United States Government. Neither the United States Government nor any agency Thereof, nor any of their employees, makes any warranty, express or implied, or assumes any legal liability or responsibility for the accuracy, completeness, or usefulness of any information, apparatus, product, or process disclosed, or represents that its use would not infringe privately owned rights. Reference herein to any specific commercial product, process, or service by trade name, trademark, manufacturer, or otherwise does not necessarily constitute or imply its endorsement, recommendation, or favoring by the United States Government or any agency thereof. The views and opinions of authors expressed herein do not necessarily state or reflect those of the United States Government or any agency thereof. 


\section{DISCLAIMER}

Portions of this document may be illegible in electronic image products. Images are produced from the best available original document. 


\section{INFORMATION CONCERNING USE OF THIS REPORT}

\section{PRELIMINARY REP()RT}

This report contains information of a preliminary nature prepared in the course of work under Atomic Energy Commission Contract AT $(45-1)-1830$. This information is subject to correction or modification upon the collection and evaluation of additional data.

\section{LEGAL NOTICE}

This report was prepared as an account of work sponsored by the United States Government. Neither the United States nor the United States Atomic Energy Commission, nor any of their employees, nor any of their contractors, subcontractors, or their employees, makes any warranty, express or implied, or assumes any legal liability or responsibility for the accuracy. completeness or usefulness of any information, apparatus, product or process disclosed, or represents that its use would not infringe privately owned rights.

PACIFIC NORTHWEST LABORATORY

operated by

BATTELLE MEMORIAL INSTITUTE

for the

U. S. ATOMIC ENERCY COMMISSION

Under Contract AT(45-1) 1830 
BNWL - B - 51

\section{ANALYSIS OF AIR PULSER PERFORMANCE FOR PULSED EXTRACTION COLUMNS}

J. D. Kaser

Chemical Technology Department Chemistry and Metallurgy Division

February 1971

This report is intended primarily for internal use by the

sponsoring organization and Battelle-Northwest.

BATTELLE MEMORIAL INSTITUTE

PACIFIC NORTHWEST LABORATORIES

RICHLAND, WASHINGTON 99352 sponsored by the United States Government. Neither the United States nor the United States Atomic Energy Commission, nor any of their. employees, nor any of their contractors, subcontractors, or their employees, makes any warranty, express or implied, or assumes any legal liability or responsibility for the accuracy, completeness or usefulness of any information, apparatus, product or process disclosed, or represents that its use would not infringe privately owned rights. 
THIS PAGE

\section{WAS INTENTIONALLY LEFT BLANK}




\section{CONTENTS}

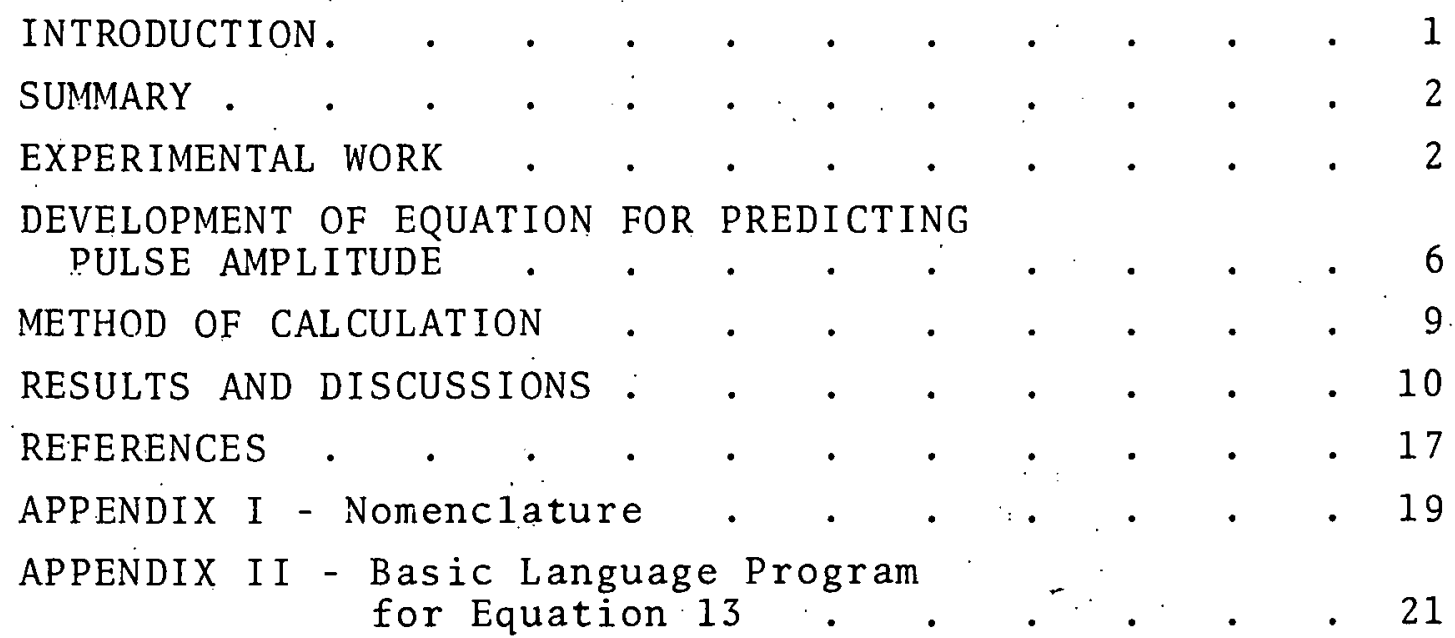

\section{LIST OF FIGURES}

1 Air Pulsed Extraction Column

2 Comparison of Calculated and Experimentally Measured Amplitude for Column Partially

Filled with Water

3 Comparison of Calculated and Experimentally Measured Amplitude for Column Completely

Filled with Water

4 Comparison of Equation 13 with Numerical Method of Weech and Knight

5 Pulse Amplitude Curves for $3 \mathrm{~A}$ Column Calculated from Equation 13

6 Pulse Amplitude Curves for 3B Column Calculated from Equation 13 


\section{ANALYSIS OF AIR PULSER PERFORMANCE FOR PULSED. EXTRACTION COLUMNS}

J. D. Kaser

\section{INTRODUCTION}

The goal of this work was to predict the pulse amplitude in $3 \mathrm{~A}$ and $3 \mathrm{~B}$ columns from information on column design, column liquid properties, pulser frequency, and pulser air supply pressure. The $3 \mathrm{~A}$ column is the extraction column and the $3 \mathrm{~B}$ column is the stripping column to be used in the third plutonium solvent extraction cycle of Hanford Purex plant. The approach taken was to develop an analytical expression for pulse amplitude and to compare amplitudes predicted by this expression with amplitudes predicted by other methods and with experimentally measured amplitudes.

V. L. Hammond ${ }^{(1)}$ calculated pulse amplitudes by assuming that the air pressure exerted on the liquid in the pulse was a square-wave function of time and by solving the resulting hydraulic differential equation by analog computer. . He further developed a simplified expression which agreed well with his analog solution when an arbitrary adjustment was made in the time constant used in the simplified expression: He did not report any experimental data for comparison.

M. E. Weech and B. E. Knight ${ }^{(2)}$ analyzed pulser performance. Using few simplifying assumptions, they derived four nonlinear differential equations whose solutions required a fairly involved numerical method performed by digital computer. However, no experimental pulse amplitude data was given to check calculations. In consequence, a review of previous work revealed the need for a simpler, but reasonably accurate 
expression for calculating pulse amplitude, and also the need for experimentally checking the calculations.

\section{SUMMARY}

An expression was derived for determining the pulse amplitude in air pulsed columns as a function of reservoir air pressure and pulse frequency: Amplitudes calculated by this expression and by V. L. Hammond's simplified equation compare favorably with experimentally measured amplitudes and with amplitudes calculated by a lengthy numerical procedure, Plots of amplitude versus reservoir air pressure were calculated at several pulse frequencies for two-pulse column designs.

\section{EXPERIMENTAL WORK}

Column 1 in EDL-102 was used for obtaining experimentally measured amplitudes for checking the accuracy of amplitudes calculated from the derived equations. The general layout of the column and associated pulser system is shown in Figure 1. Air pressure is regulated by a two-mode controller and pressure fluctuations are minimized by the capacitance of the air reservoir. Nir is admitted to and from the pulse leg through the three-way solenoid valve. The liquid in the pulse leg osciilates about a mean height, $X$, above the pulse leg connection while the liquid level in the column is maintained at a height, $\mathrm{H}$, by the organic take-off weir. A small purge of either fresh organic or aqueous solvent may be admitted to the pulse to reduce contamination and fouling.

In order to test the two methods for calculating pulse amplitude, pulse amplitudes were measured with the column both completely filled and partly filled with water. The change in water levels effectively changed the number of plates and the 


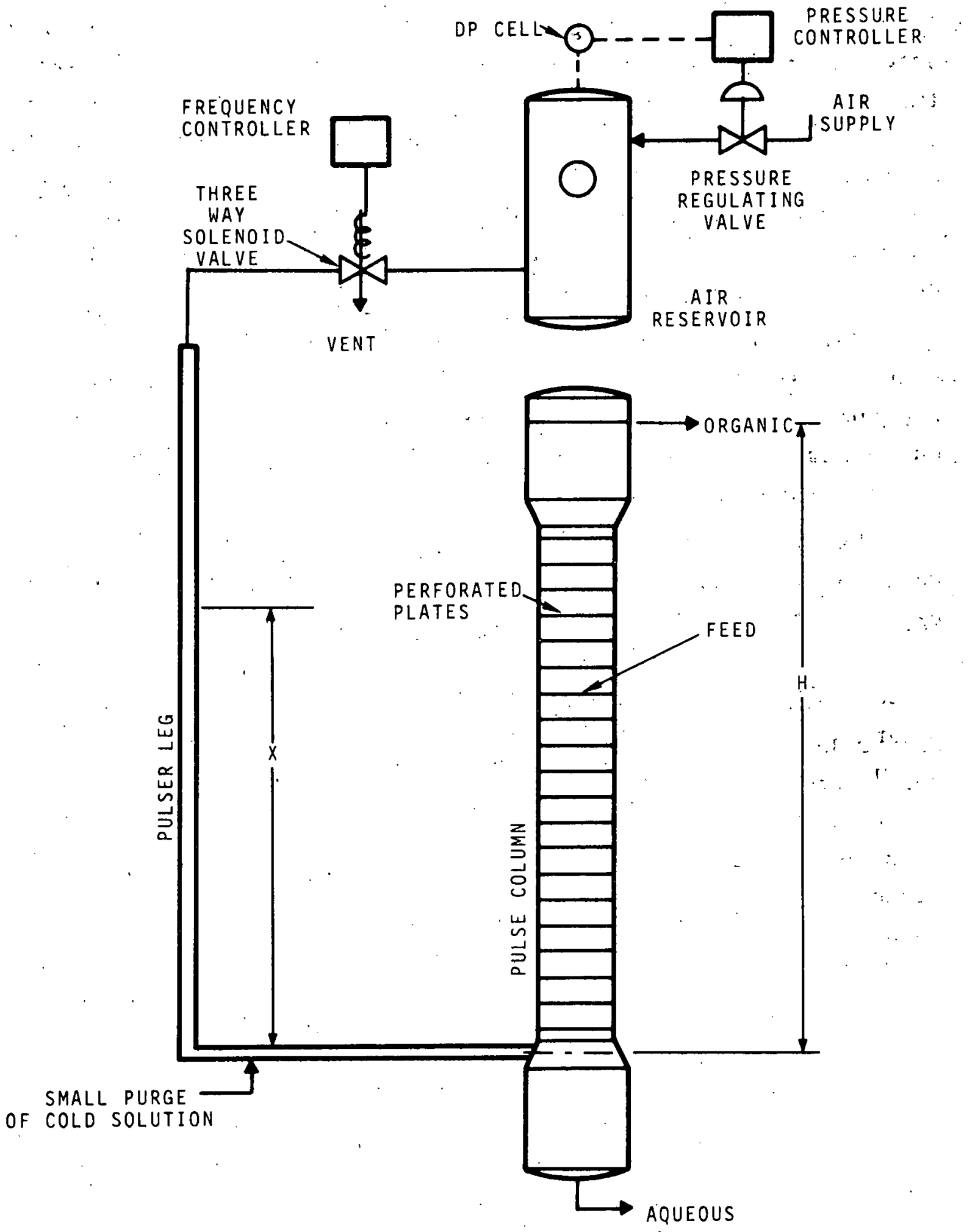

FIGURE 1. Air Pulsed Extraction Column 
length of the pulser leg and column. There was no net flow of water through the column during the experiments. Pulse amplitudes for the column were calculated from the measured amplitude in the pulse $l e g$ and the ratio of the cross-sectional areas of pulse 1 eg and column. The pulse leg amplitude was taken to be the difference between the maximum and minimum levels of liquid in the pulse leg as measured with a ruler during steady operation of the pulser.

During measurement, the pulse frequency was held constant at $40,6 b$, and gu cycles/min. The pulse frequency is the number of times per minute that air is admitted to the pulse leg or alternatively, the number of times per minute that air is exhausted from the pulse $1 \mathrm{eg}$.

Reservoir air pressure was measured by a Bourdon gage. Descriptive data for the column are listed in Table 1 , while experimentally observed amplitudes are given in Table 2.

TABLE 1. Description of EDL-102 Column 1

Column Height, ft

Pulse Leg Inside Diameter, ft

Column Injidc Diamcter, ft

Density of water in Column, $I b / f t^{3}$

Viscosity of Water, lb/ft-sec

Column plates,

57 with 23\% free area

10 with $37 \%$ free area

3 with 25\% free area

Average Free Area, \%

Equivalent Length of Bends and Horizontal Runs in Pulse Leg, ft
23.5

0.0833

0.250

62.4

$6.72 \times 10^{-4}$

70

24

2.0 
TABLE 2. Experimentally Measured Pulse Amplitude

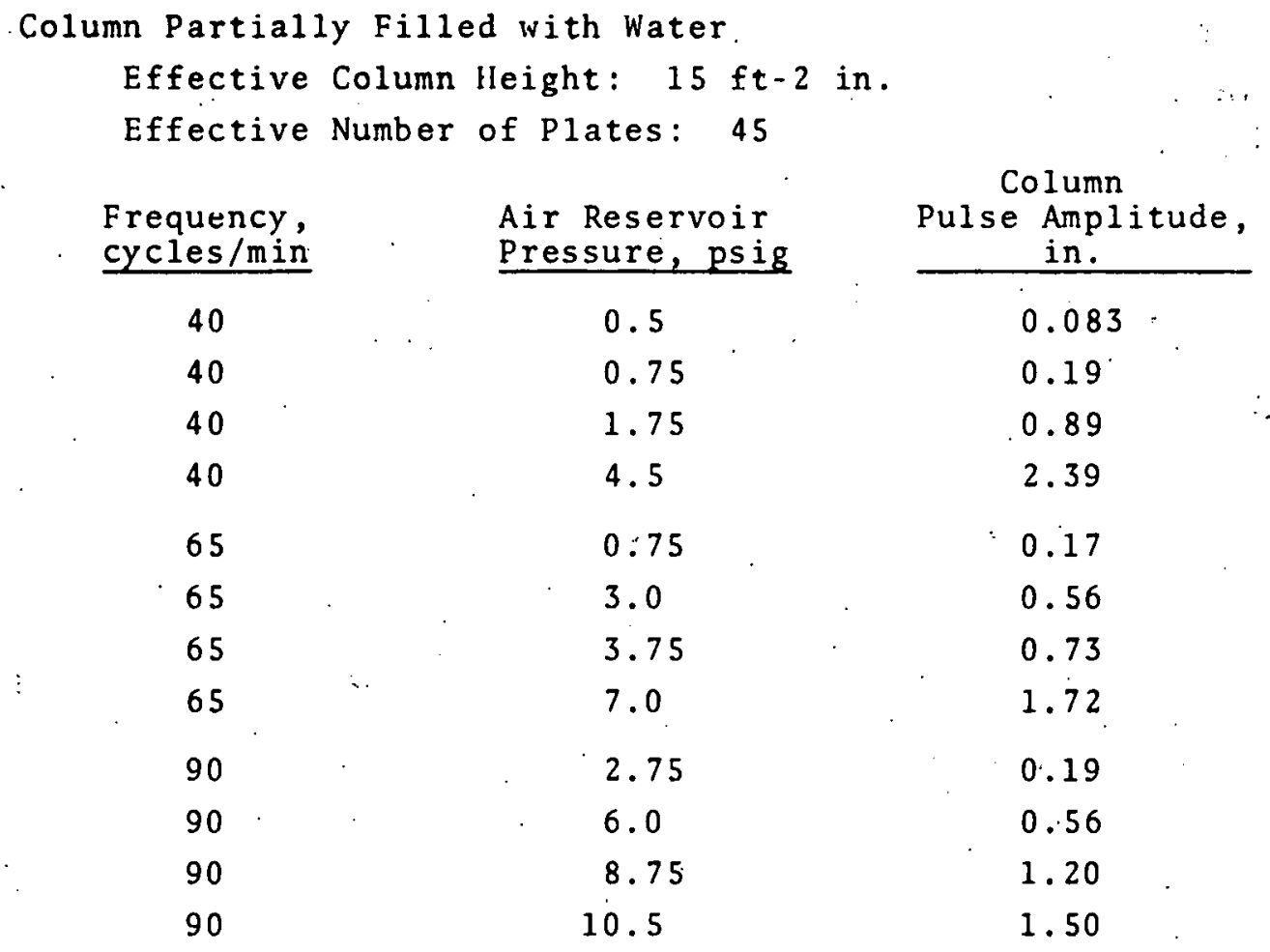

Column Completely Filled with Water

Column Height: $23.5 \mathrm{ft}$

Number of Plates: 70

\begin{tabular}{ccc}
$\begin{array}{c}\text { Frequency } \\
\text { Cycles/min }\end{array}$ & $\begin{array}{c}\text { Air Reservoir } \\
\text { Pressure, psig }\end{array}$ & $\begin{array}{c}\text { Column } \\
\text { Pulse Amplitude, } \\
\text { in: }\end{array}$ \\
\hline $\begin{array}{c}1.0 \\
40\end{array}$ & 1.75 & 0.25 \\
40 & 3.0 & 0.45 \\
40 & 4.5 & 0.75 \\
40 & 4.5 & 1.44 \\
65 & 5.75 & 0.44 \\
65 & 7.25 & 0.67 \\
65 & 9.0 & 0.89 \\
65 & 4.25 & 1.14 \\
90 & 7.0 & 0.47 \\
90 & 8.25 & 0.78 \\
90 & 11.0 & 0.92 \\
90 & & 1.22
\end{tabular}




\section{DEVELOPMENT OF EQUATION FOR PREDICTING PULSE AMPLITULE}

The starting point for the development of the pulse amplitude equation is the differential equation for liquid flow as stated by Weech and Knight. (2)

$$
\begin{aligned}
& {\left[\frac{\rho_{m} H}{g_{C}}\left(\frac{A_{L}}{A_{c}}\right)+\frac{\rho_{L} X}{g_{C}}\right] \frac{d^{2} X}{d t^{2}}+\left[\rho_{m}\left(\frac{A_{L}}{A_{O}}\right)^{2} \frac{N}{2 g_{C} C^{2}}\right.} \\
& \left.+\frac{2 \rho_{\rho_{L}}\left(X_{C}+X\right)}{g_{C} V_{L}}\right]\left(\frac{d X}{d t}\right)^{2}+\frac{g}{g_{C}}\left(\rho_{L} X{ }_{{ }_{m}} H\right)=\Gamma_{t} \cdot
\end{aligned}
$$

Equation 1 was linearized by making the following assumptions:

1. That $x$ could be considered constant at its mean value during pulsing;

2. That $\left(\frac{d x}{d t}\right)^{2} \approx\left(\frac{d x}{d t}\right)_{\max }\left(\frac{d x}{d t}\right)$ where $\left(\frac{d x}{d t}\right)_{\max }=$ the maximum value of liquid velocity in the pulse leg; and

3. That $f$, the friction factor, is a function of the average speed of the liquid in the pulse leg taken to be twice the product of the amplitude and frequency.

The expression used to calculate the friction factor is:

$$
F=0.0014+0.125\left(\frac{{ }^{\mu} L}{D_{L} \cdot 2 \omega a_{L}{ }^{\rho} L}\right)^{0.32} .
$$

The air pressure above the liquid in the pulse leg is assumed to be a sinusoidal function of time fluctuating at the pulse frequency between a maximum value equal to the air reservoir pressure and a minimum pressure of zero:

$$
\mathrm{P}_{\mathrm{t}}=\frac{1}{2} \mathrm{P}_{\mathrm{r}} \sin 2 \pi \omega \mathrm{t}+\frac{1}{2} \mathrm{P}_{\mathrm{r}}
$$

A further simplification was made that the mean difference in liquid head between the column and pulse leg is equal to the mean air pressure in the pulse leg. 
BNWL - B - 51

$$
\rho_{\mathrm{m}} \mathrm{H}-\rho_{\mathrm{L}} \mathrm{X}=\frac{1}{2} \mathrm{P}_{\mathrm{r}} \text {. }
$$

Linearization of Equation 1 and elimination of Pt and $X$ by use of Equation 4 results in the following second order linear differential equation:

$$
\begin{aligned}
& \frac{d^{2} x}{d t^{2}}+A_{1} \frac{d x}{d t}=B \sin k t \\
& \qquad\left[\rho_{m}\left(\frac{A_{L}}{A_{o}}\right)^{2} \frac{N}{2 g_{C} C^{2}}+\frac{2 f \rho_{L}\left(x_{e}+\frac{\rho_{m} H-\frac{1}{2} P r}{\rho_{L}}\right)}{g_{C} D_{L}}\right] V_{m a x}
\end{aligned}
$$

where, $\mathrm{A}_{1}=$

$$
\frac{\rho_{m} H}{g_{C}}\left(\frac{A_{L}}{A_{C}}+1\right)-\frac{P_{r}}{2 g_{c}}
$$

$$
B=\frac{-\frac{1}{2} P_{x}}{\frac{\rho_{m} H}{g_{c}}\left(\frac{A_{L}}{A_{c}}+1\right)-\frac{P_{r}}{2 g_{c}}}
$$

and $\quad K=2 \pi \omega$

The following initial conditions were assumed:

$$
\begin{aligned}
& \frac{d^{2} x}{d t^{2}}=0 \\
& \frac{d x}{d t}=0
\end{aligned}
$$

By use of Laplace transforms, the following solution to Equation 5 is obtained:

$$
\begin{aligned}
X= & x_{0}+\frac{B}{A_{1} k}+\frac{B k}{A_{1}\left(A_{1}^{2}+k^{2}\right)} e^{-A_{1} t}-\frac{A_{1} B}{k\left(A_{1}^{2}+k^{2}\right)} \cos k t \\
& -\frac{B}{A_{1}^{2}+k^{2}} \sin k t .
\end{aligned}
$$


The maximum and minimum velocities and displacements are found by successive differentiation of Equation 6 and by setting the appropriate derivatives equal to zero. The maximum velocity in the pulse leg is:

$$
\left(\frac{d x}{d t}\right)_{\max }=\frac{B}{\left(A_{1}^{2}+k^{2}\right)^{1 / 2}}=V_{\max } .
$$

The maximum displacement is:

$$
x_{\max }=x_{0}+\frac{B}{A_{1} k}+\frac{B}{k\left(A_{1}^{2}+k^{2}\right)^{1 / 2}}
$$

and the minimum displacement is:

$$
x_{\min }=x_{0}+\frac{B}{A_{1} k}-\frac{B}{k\left(A_{1}^{2}+k^{2}\right)^{1 / 2}} .
$$

The pulse amplitude in the pulse leg is the difference. between $x_{\max }$ and $x_{\min }$ :

$$
a_{L}=\frac{2 B}{k\left(\Lambda^{2} V_{\max }^{2}+k^{2}\right)}
$$

By comparing Equations 7 and 10 , it can be seen that:

$$
a_{L}=\frac{2 V_{\text {max }}}{k}
$$

By substituting Equation 11 for $V_{\text {max }}$ in Equation 10 and solving the resulting quadratic equation for $a_{L}$, the amplitude, we arrive at the expression for pulse amplitude in the pulse leg:

$$
a_{L}=\frac{2}{A k} \sqrt{\frac{-k^{2}+\sqrt{k^{4}+4 A^{2} B^{2}}}{2}}
$$

where $A=A_{1} / V_{\max }$. 
Multiplication of Equation 12aby the ratio of pulse leg cross-sectional area to column cross-sectional area and converting from feet to inches, we obtain the final.working equation for calculating pulse amplitude in the column:

$$
a_{c}=\frac{24}{A k}\left(\frac{D_{L}}{D_{c}}\right)^{2} \sqrt{\frac{-k^{2}+\sqrt{k^{4}+4 A^{2} B^{2}}}{2}} \text {. }
$$

\section{METHOD OF CALCULATION}

The use of Equation 13 involves a straightforward substitution of numerical values for the quantities indicated. However, two peculiarities of Equation 13 should be explained:

First, an iterative solution for the amplitude is required since the pulse amplitude affects the value of the friction factor $f$, as shown in Equation 2, which in turn affects the value of $A$ in. Equation 13. Therefore, a first guess of the amplitude must be made to obtain a value of $f$, then the resulting amplitude calculated from Equation 13 is used to calculate an improved value for $f$ and the process is repeated. Satisfactory convergence is usually obtained in two or three interations.

The second peculiarity involving the evaluation of the term $\frac{A_{L}}{A_{0}}$ in Equations 1 and 5 arises from the fact that pulse columns may contain several kinds of plates with different hole areas. Since $N$ is the total number of plates, a properly averaged hole area, $A_{0}$, must be used., The resis-. tance of the various kinds of plates is additive. Noting thal $A_{O}=e A_{C}$, wc can write:

$$
\left(\frac{A_{L}}{A_{0}}\right)^{2} N=\left(\frac{A_{L}}{A_{C}}\right)^{2} \frac{N}{e^{2}}=\left(\frac{A_{L}}{A_{C}}\right)\left(\frac{N 1}{e_{1}^{2}}+\frac{N 2}{e_{2}^{2}}+\ldots\right)
$$


Therefore, the average fractional hole is:

$$
e^{2}=\frac{N}{\frac{N 1}{e_{1}^{2}}+\frac{N 2}{e_{2}^{2}}+\ldots}
$$

where $e$ is the average fractional hole area for all plates in the column.

To save time, the curves user in this report wcre calcu= lated from Equation 1.3 hy digital computer using a DASIC language program listed in Appendix II. BASIC language is a conversational system used with time-sharing teletype terminals provided by Computer Science Corporation.

V. L. Hammond's(1) simplified expressinn for pulse ampli. tude, using the nomenclature of the present report is:

$$
\dot{a}_{L}=-\frac{1}{A} \ln \left\{1-\left[\frac{-1+\exp \left(\frac{1}{2 \omega} \sqrt{-A B}\right)}{1+\exp \left(\frac{1}{2 \omega} \sqrt{-A B}\right)}\right]\right\} \text {. }
$$

This equation includes Hammond's assumption that the amplitude is twice the displacement occurring during the first one-fourth cycle time when the liquid moves upward in the pulse leg from its level of maximum depression.

\section{RESULTS ANO OISCU'SIONS}

To gain confldence in the accuracy of Equation 13 and 16 , calculated pulse amplitudes were comparcd with measured anplitudns (given in Table 2) for an EDL-1UL culumn filled with water to heights of $15 \mathrm{ft} 2 \mathrm{in}$. and $23 \mathrm{ft}$ and 6 in. The comparisons for the column filled to a height of $15 \mathrm{ft} 2$ in. are shown in Figure 2 and the romparisons for the column completely filled with water to a height of $23 \mathrm{ft} 6 \mathrm{in}$. are shown in Figure 3. Equation 13 agrees better with the experimental 


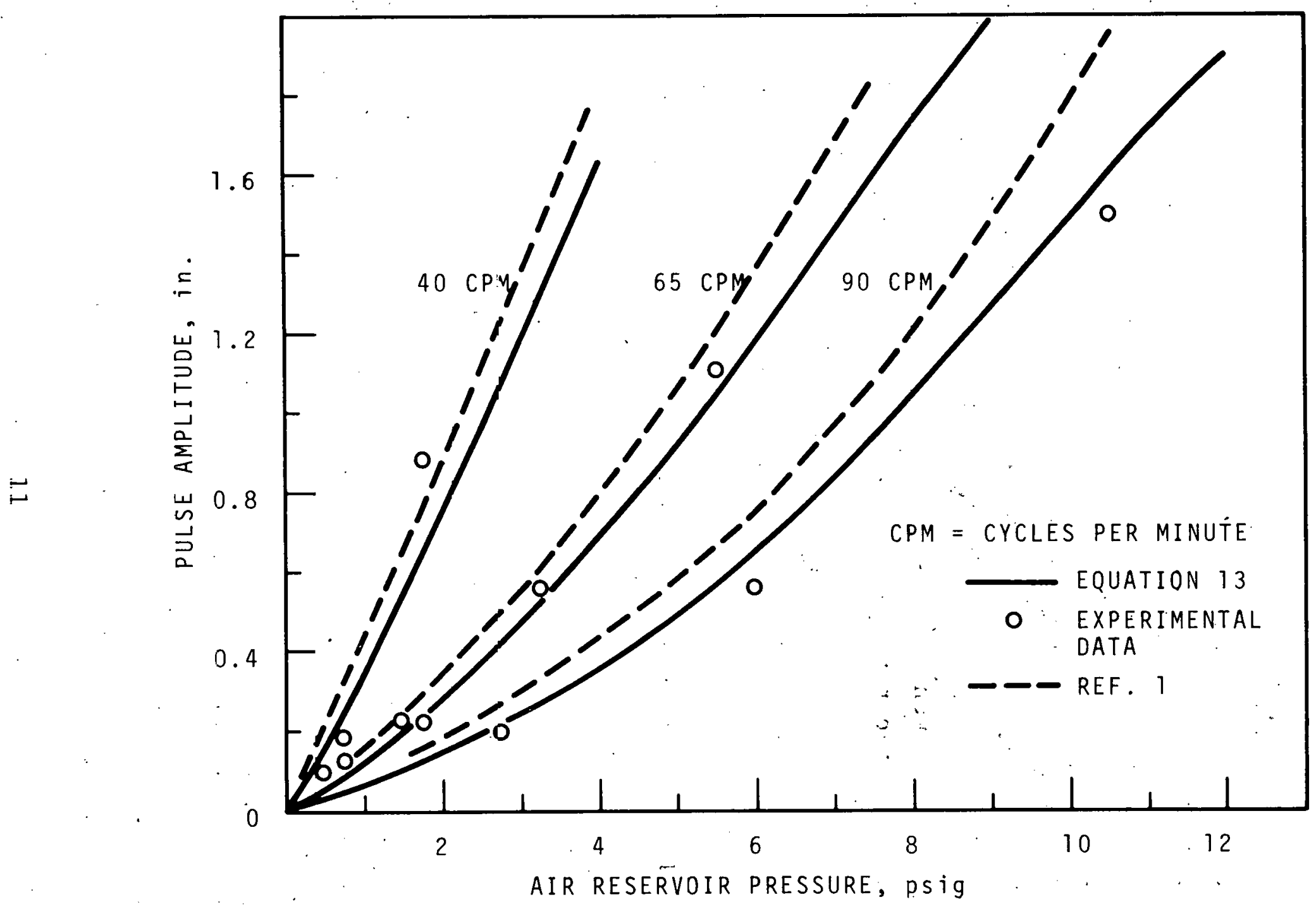

FIGURE 2. Comparison of Calculated and Experimentally Measured Amplitude for Column Partially 


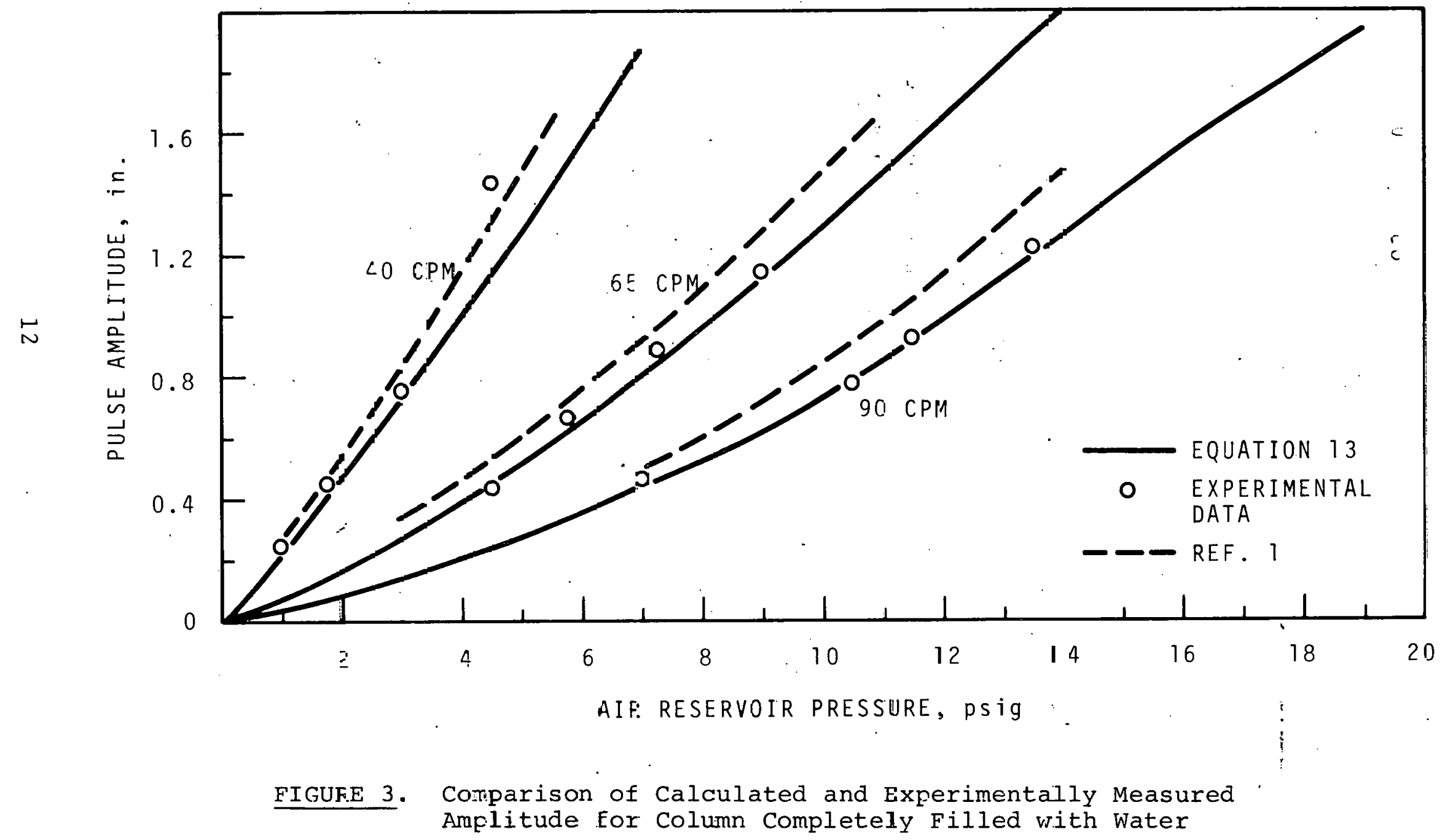


data at the higher frequencies of 65 and 90 cycles/min, where the assumption of a sinusoidal variation of air pressure in the pulse leg appears to be more reasonable than the assumption of a square wave air pressure variation. However; at the lowest frequency of 40 cycles/min, Equation 16, which assumes a square wave air pressure function, agrees better with the experimentai data.

It may be concluded that either Equations.13 and $16^{\circ}$ can be used for rough estimates, while for more accurate predictions Equation 16 should be used for frequencies below about 50 cycles/min and Equation 13 should be used for frequencies higher than 50 cycles/min.

Another test of Equation 13 was made by comparing.calculated pulse amplitudes versus pressure curves for the column described in Reference 2 with the curves calculated by Weech and Knight. Again, agreement appears to be satisfactory as shown in Figure 4.

Finally, amplitude-pressure curves were calculated for $3 \mathrm{~A}$ and $3 \mathrm{~B}$ Columns and are given in Figures 5 and 6 , respectively. These curves can be used to determine the reservoir air pressure required.

The values of the variables used for these columns are listed in Table 3 . 


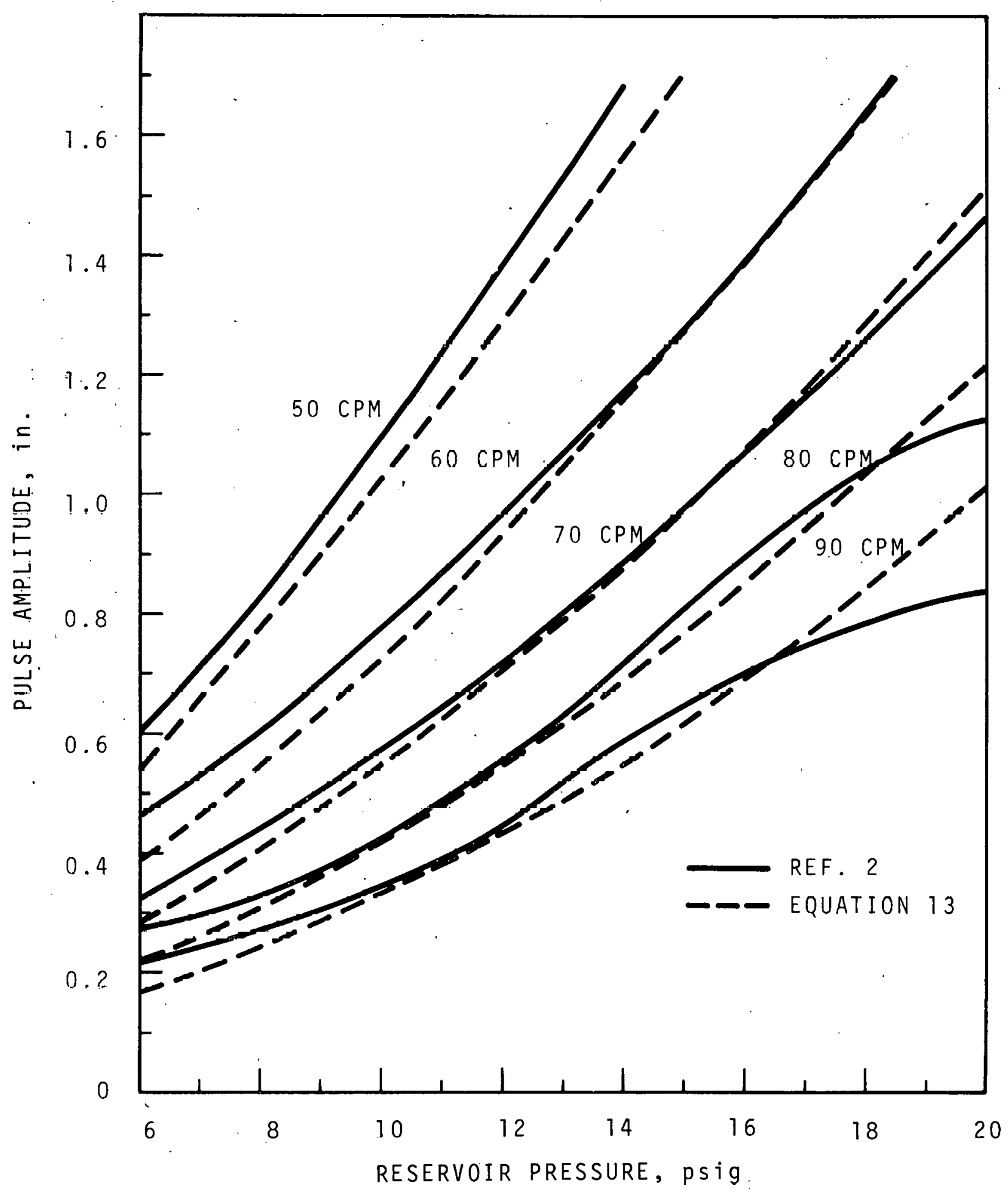

FIGURE 4. Comparison of Equation 13 with Numerical Method of Weech and Knight 


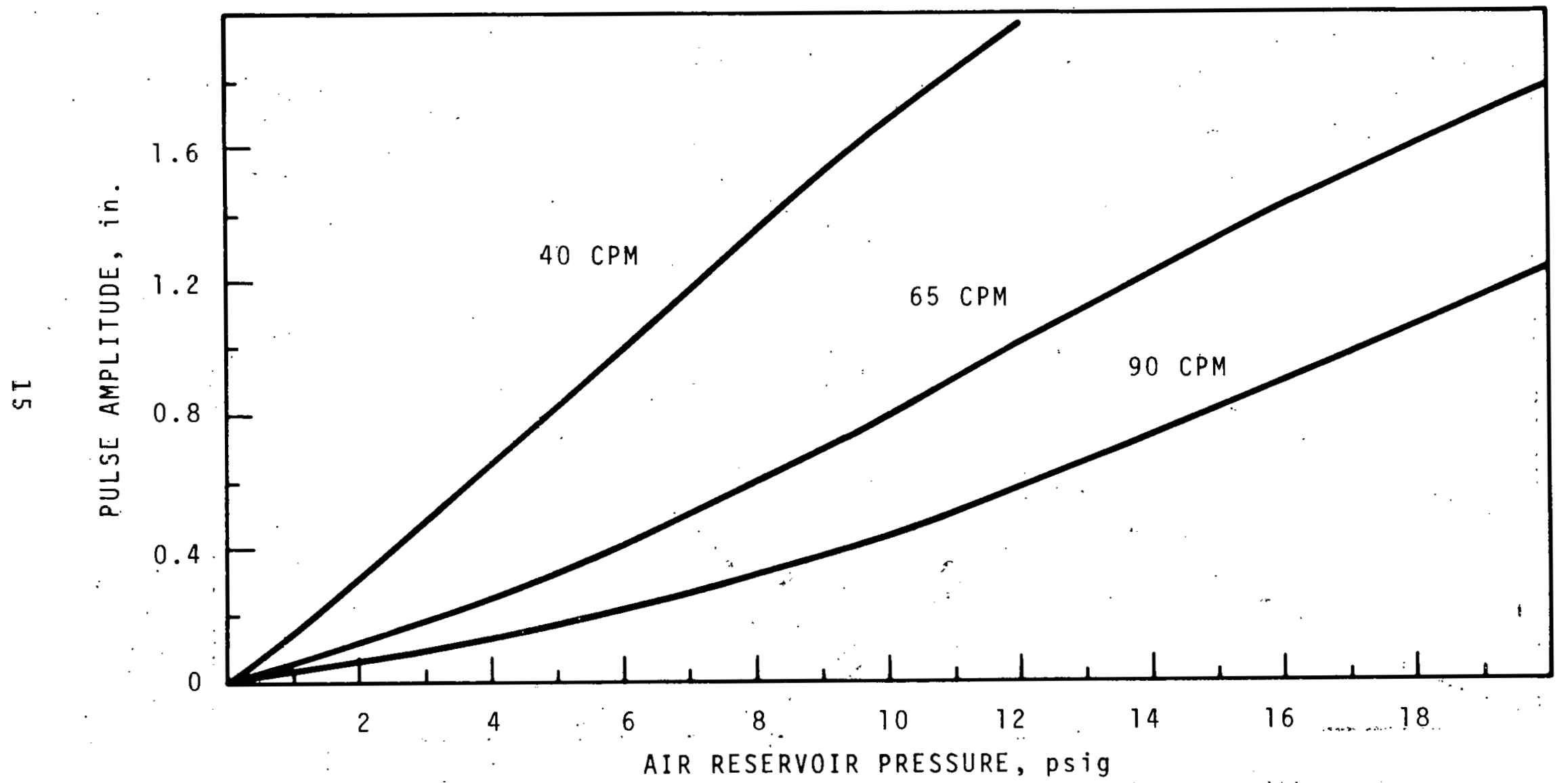

FIGURE 5. Pulse Amplitude Curves for 3A Column Calculated from Equation 13 


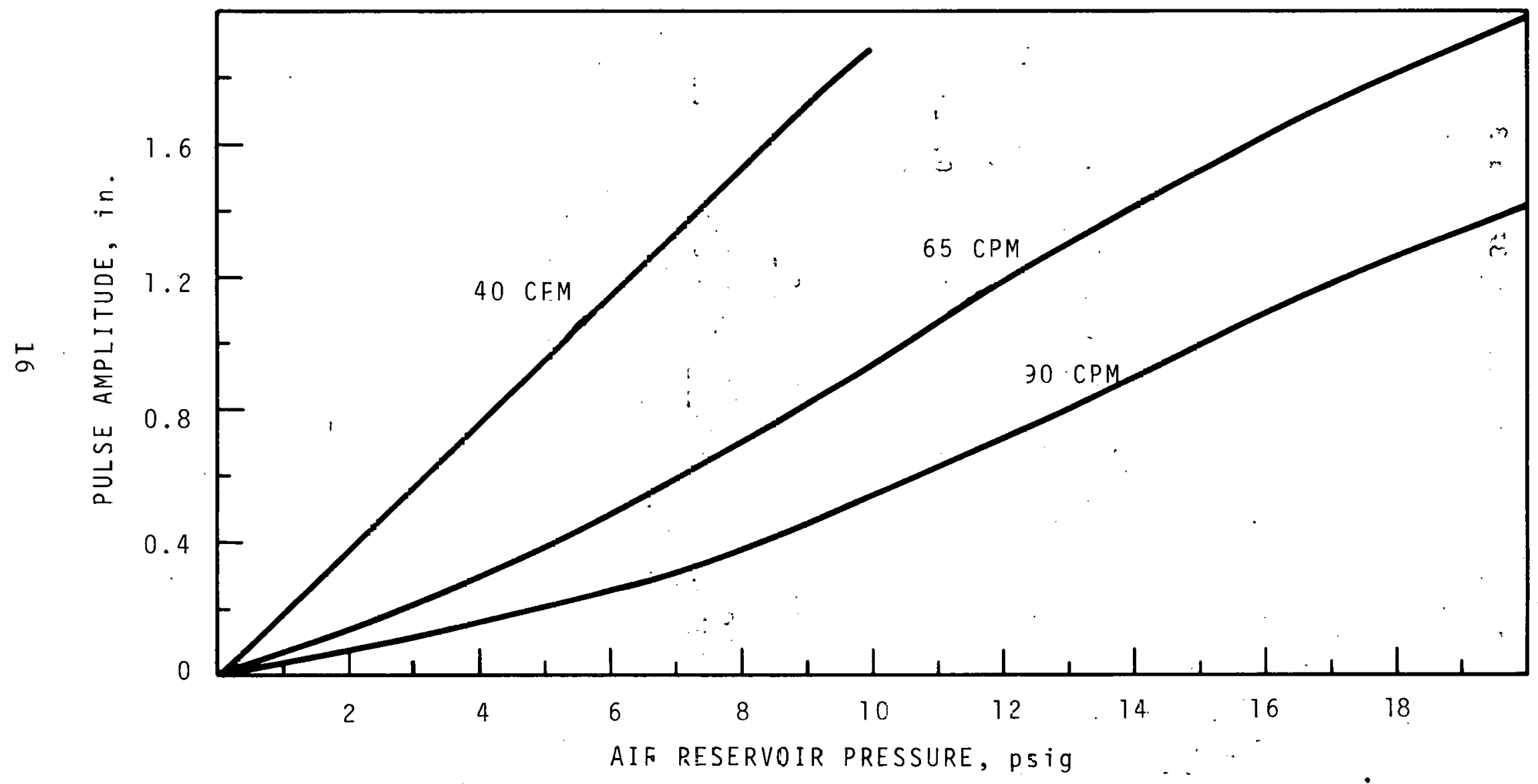

FIGURE 6. Pulse Inplitude Curves for 3B Colum Calcnlated from Equation 13 
BNWL - B - 51

TABLE 3. Description of $3 A$ and $3 B$ Columns

\begin{tabular}{|c|c|c|}
\hline & 3A Column & 3B Column \\
\hline Column Height, ft & 33 & 25.7 \\
\hline Column Diameter, ft & 00.2957 & 0.2957 \\
\hline Pulse Leg Diameter, ft & 0.0874 & 0.0874 \\
\hline $\begin{array}{l}\text { iquid Density in Pulse Leg, } \\
\text { lb mass/ft } 3\end{array}$ & $\begin{array}{l}50.5 \\
53.7\end{array}$ & $\begin{array}{l}62.4 \\
61.2\end{array}$ \\
\hline $\begin{array}{l}\text { Average Liquid Density in Column, } \\
\text { lb mass/ft }\end{array}$ & & \\
\hline $\begin{array}{l}\text { quivalent Length of Fittings, Bends, } \\
\text { and Horizontal Pipe in Pulse Leg, ft }\end{array}$ & 15.75 & 11.9 \\
\hline $\begin{array}{l}\text { iscosity of Pulse Leg Liquid, } \\
\text { lb mass/ft-sec }\end{array}$ & 0.000941 & 0.000672 \\
\hline tal Number of Plates & 159 & 122 \\
\hline lerage Fractional Hole Area in Plates & 0.224 & 0.229 \\
\hline ifice Coefficient & 0.75 & 0.75 \\
\hline
\end{tabular}

\section{REFERENCES}

1. V. L. Hammond. Hydraulic Characteristics of Air-Pulsed Solvent Extraction Columns, $H W-70489$. Available from National Technical Information Service, springfield, Virginia. January 1962.

2. M. E. Weech and B. E. Knight." "Design of Air Pulsers for Pulse Column Application," I\&EC Process Design and Development, vol. 6, no. 4, pp. $48 \overline{0-486.1987 .}$ 
BNWL - B - 51

\section{APPENDICES}

NOMEN CLATURE

BASIC LANGUAGE PROGRAM FOR EQUATION 13 


\section{APPENDIX I}

NOMENCLATURE

\begin{tabular}{|c|c|c|}
\hline $\begin{array}{c}\text { Symbol } \\
\text { in Report }\end{array}$ & $\begin{array}{l}\text { Symbol } \\
\text { in Computer } \\
\text { Program } \\
\end{array}$ & Definition \\
\hline $\mathrm{A}$ & A & $\mathrm{A}_{1} / \mathrm{V}_{\max }, \mathrm{ft}-1$ \\
\hline$A_{1}$ & $\therefore$ & Defined by Equation $5, \sec ^{-1}$ \\
\hline$A_{C}$ & & $\begin{array}{l}\text { Cross-sectional area of pulse } \\
\text { column, ft }\end{array}$ \\
\hline$A_{0}$ & & Hole area in column plate, $\mathrm{ft}^{2}$ \\
\hline$A_{L}$ & & $\begin{array}{l}\text { Cross-sectional are of pulse leg, } \\
\text { ft } t^{2}\end{array}$ \\
\hline$a_{c}$ & $\mathrm{~J}$ & Pulse amplitude in column, in. \\
\hline$a_{L}$ & & Pulse amplitude in pulse leg, ft \\
\hline B & B & Defined by Equation 5 \\
\hline $\mathrm{C}$. & $\mathrm{C}$ & Orifice coefficient \\
\hline$D_{c}$ & $\mathrm{D} 2$ & Column diameter, ft \\
\hline $\mathrm{D}_{\mathrm{L}}$ & D1 & Pulse leg diameter, ft \\
\hline e & $\mathrm{F} 1$ & Fractional hole area in column plate \\
\hline $\mathrm{f}$ & $\mathrm{F}$ & Friction factor defined by Equation 2 \\
\hline $\mathrm{g}$ & G & Gravitational acceleration, $f t / \mathrm{sec}^{2}$ \\
\hline$g_{C}$ & G & $\begin{array}{l}\text { Dimensional conversion factor, } \\
32.2 \text { lb mass/1b force-sec }\end{array}$ \\
\hline $\mathrm{H}$ & $\mathrm{H}$ & $\begin{array}{l}\text { Height of liquid in column above } \\
\text { pulse leg inlet, ft }\end{array}$ \\
\hline $\mathrm{k}$ & $\mathrm{K}$ & $2 \pi \omega, \sec ^{-1}$ \\
\hline $\mathrm{N}$ & $\mathrm{N}$ & Number of column plates \\
\hline $\operatorname{Pr}$ & $\mathrm{P}$ & $\underset{f t}{\operatorname{Pres}} \underset{\mathrm{fure}}{\mathrm{in}}$ air reservoir, $1 \mathrm{~b}$ force/ \\
\hline $\mathrm{Pt}$ & & Air pressure in pulse leg, lb force/ \\
\hline$t$ & & Time, sec \\
\hline $\mathrm{X}$ & & $\begin{array}{l}\text { Height of liquid in pulse leg above } \\
\text { inlet to column, ft }\end{array}$ \\
\hline $\mathrm{x}_{\mathrm{e}}$ & $\mathrm{X}$ & $\begin{array}{l}\text { Equivalent length of fittings, bends, } \\
\text { and horizontal pipe in pulse leg, } \\
\text { ft }\end{array}$ \\
\hline
\end{tabular}




$\begin{array}{cc}\begin{array}{c}\text { Symbo1 } \\ \text { in Report }\end{array} & \begin{array}{c}\text { Symbol } \\ \text { in Computer } \\ { }_{\mathrm{L}}\end{array} \\ \rho_{\mathrm{m}} & \mathrm{M} \text { R } 2 \\ { }^{\rho_{\mathrm{L}}} & \mathrm{R} 1 \\ \omega & \mathrm{W}\end{array}$

Definition

Viscosity of liquid in pulse leg, lb mass/ft sec

Average dnesity of 1 iquid in column, 1b mass/ft 3

Density of pulse leg liquid, $1 b$ mass $/ \mathrm{ft}^{3}$

Pulse frequency., $\sec ^{-1}$ 


\section{APPENDIX II}

\section{BASIC LANGUAGE PROGRAM FOR EQUATION 13}

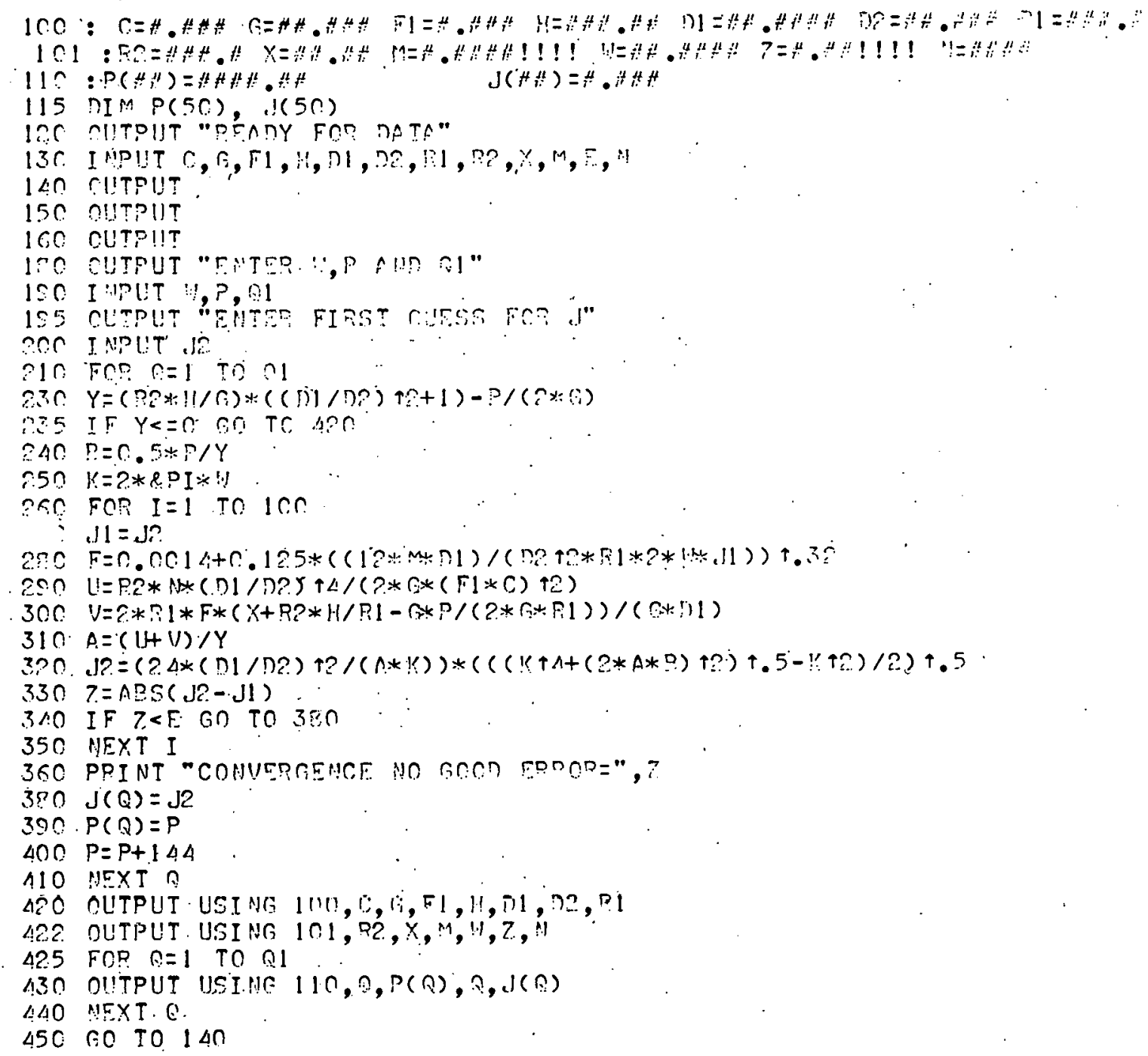




\section{DISTRIBUTION}

OFFSITE

1

AEC Chicago Patent Group:

G. H. Lee

2

AEC Division of Technical Information Extension

\section{ONSITE-HANFORD}

1

AEC Chicago Patent Group

R. M. Potieat

11

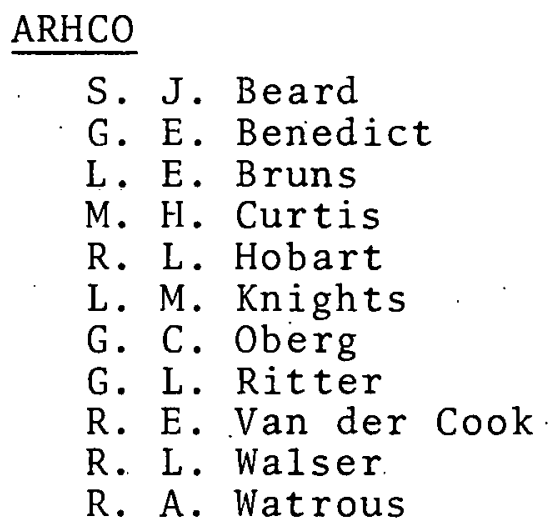

$1 \quad$ WADCO

G. L. Richardson

22 Battelle-Northwest

R. E. Burns

D. R. de Halas

G. Jansen, Jr.

J. D. Kaser (10)

L. K. Mudge

R. E: Nightingale

L. D. Perrigo

K. J. Schneider

Technical Information (3)

Technical Publications (2) 